\title{
軌道アトラクタを用いた自律制御系に基づく擬似目標値*
}

岡田 昌史 ${ }^{* 1}$, 渡辺 将旭*1

\section{Pseudo-Reference Based on Autonomous Control System with an Orbit Attractor}

\author{
Masafumi OKADA*1 and Masaaki WATANABE \\ ${ }^{* 1}$ Dept. of Mechanical Sciences and Engineering, Tokyo Institute of Technology \\ 2-12-1 Ookayama,Meguro-ku, Tokyo 152-8552
}

For robot-robot or human-human motion instruction, a reference motion pattern is required to show how to move. The reference will be an enhanced motion pattern because of time delay or latency of the closed loop system. In this paper, we propose "Pseudo-reference" that is derived from an autonomous control system based on an orbit attractor. The nonlinear controller is decomposed into a feedback gain and pseudo-reference which is a virtual target posture. Even though the feedback controller is unknown, it can be estimated from the nonlinear controller, and pseudo-reference is obtained. The simulations using an inverted pendulum system show the appropriateness of the pseudo-reference for a reference pattern, and the experiments using a tap dancing robot demonstrates that the estimated controller also leads an appropriate reference pattern.

Key Words : Motion Instruction, Pseudo-Reference, Attractor Design, Autonomous Control System

\section{1.は じ め に}

ロボットがある運動 ヨを実現しているときに光の運動を他のロボットにも実現させる，すなわち，運動を伝え る場合を考える．これを人で例えれば，ある人の運動を他人に教示することに相当する．一般に，ロボットの運 動は図 1 に表されるようにコントローラ $K$ によって構成されたフィードバック系に目標姿勢 $\boldsymbol{r}$ をえることで生 成されているため, 運動を伝えるためには $\Xi$ 基づいた逆問題の解から得られる $\boldsymbol{r}$ をえればよいが，これは $K$ に大きく依存する.$K$ はフィードバック系の内部に存在するため, ロボットと環境のインタラクションが制御可

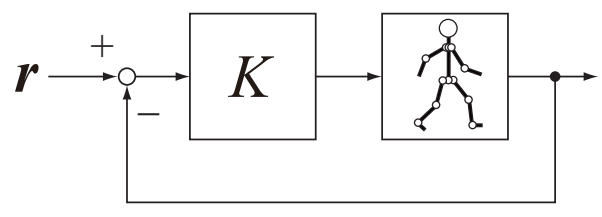

Fig. 1 Feedback loop system for robot motion generation

能である一方で，ロボットを安定化させる必要がある．環境に固定されたロボットであれば $K$ の設計，および， $\boldsymbol{r}$ を求めることは容易であるが, 例えば歩行ロボットのような劣駆動系の制御ではこれらか難しい，高西ら ${ }^{(1)}$ は姿勢 に応じて目標值制御とインピーダンスハルク制御を切り替えることで動歩行を制御する方法を，梶田ら ${ }^{(2)}$ は歩行 ロボットを倒立振子としてモデル化することで位置エネルギーが保存されるように関節を制御する方法を，真島 ら (3)は運動学に基づいてロボットの動歩行をロバスト位置制御により行う方法を古くから提案してきた .このよ うに，Kの設計において運動に依存した簡略化モデルや $K$ の切り替えが必要となり，rの設計も複雑になる . -

\footnotetext{
* 原稿受付 2012 年 6 月 21 日

*1 正員, 東京工業大学理工学研究科機械物理工学専攻（广152-8552 東京都目黒区大岡山 2-12-1）

E-mail: okada@mep.titech.ac.jp
} 
方，一般に $\boldsymbol{r}$ は外部から与えられる時間関数となるため, 既知の環境において力学的な整合性を満たす実現可能な

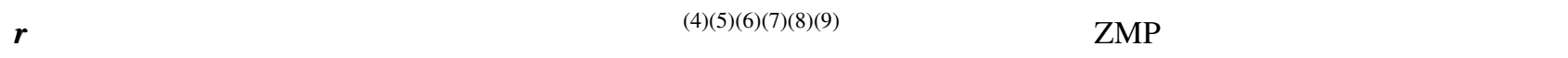
卜の目標パターンを求める方法が提案されており，金島ら ${ }^{(10)}$ は数ステップ先までの歩行パターンを生成するモデ ル予測制御を，池田ら ${ }^{(11)}$ は 1 脚ロボットのジャンプ運動に対して目標運動パターンを微分方程式で表す方法を提 案している．これらは主に実現すべき，あるいは，伝えるべき運動 この設計法であり，これを $\boldsymbol{r}$ としてえても フィードバック系の遅れによって れはフィードバック系のロバスト安定化を著しく損ねる .これらの考察から，簡易な $K$ の利用と $K$ にるフィー ドバック系の遅れなどを考慮した適切な $\boldsymbol{r}$ の設計が有効であるといえる .

適切な $\boldsymbol{r}$ を求めることは人間への運動教示においても要求される . 例えば , 教科書などでは図 2 のような連続 写真が用いられる場合が多い．これは走り幅跳びにおいて競技者が運動を行った結果であり，実現すべき運動

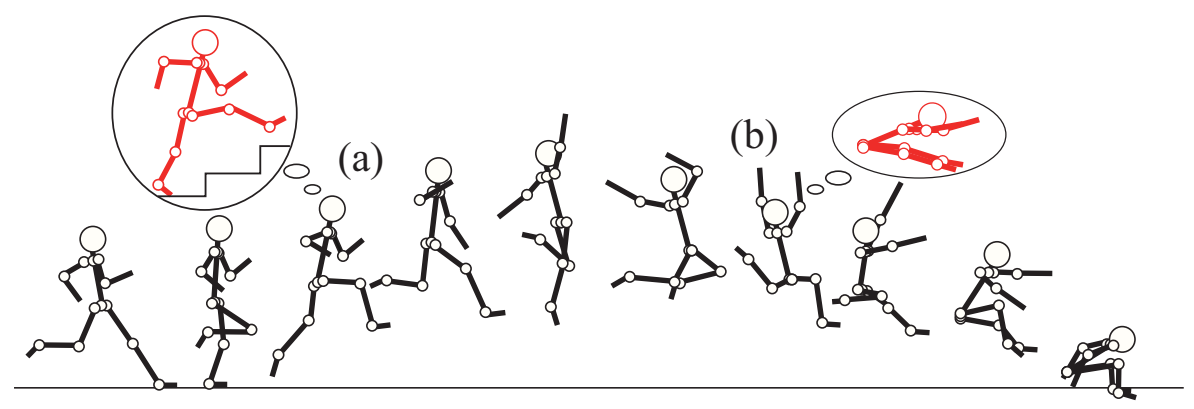

Fig. 2 The sequence posture of long jump

に相当する .この運動を実現するためには，例えば (a)では「階段を駆け上るように」, (b) では「頭と脚を前に出 す」といった言葉が付け加えられる．この言葉は，すでに運動を獲得した熟練者が, 訓練者は自分と同樣の身体 制御ルールを持っているという仮定のもと，強調した目指すべき姿勢を直感的に言葉で表したものであろう．この 言葉を図 2 中に示されるような姿勢として表し,「この姿勢を目指して」と指示すれば適切に運動の教示が行える と考えられる .

我々はこれまでに実現すべき運動るを生成させるための自律制御系の設計法を提案してきた ${ }^{(12)}$.これはるが状 態空間内で軌道アトラクタとなるよう非線形状態フィードバック則を得るものであり，ロボットは自律系として運 動を生成する. 光のため, 外部からの $\boldsymbol{r}$ は存在しないが, フィードバック系の中から仮想的な目標姿勢を導き出 すことができれば，これはすを実現するための強調した $\boldsymbol{r}$ となり得る . 本論文では, 軌道アトラクタに基づいた 自律制御系のコントローラを $K$ と $\boldsymbol{r}$ に分解し，自律制御系の中に陰に存在する仮想的な目標姿勢を擬似目標值と して導く .また，擬似目標值が運動を実現するための目標姿勢を与えていること，さらに，Kが末知であっても光 の推定値を用いることで擬似目標值か設計可能であることを示す．ただし，本論文中では周期的な運動を対象に することにする．

\section{2. 軌道アトラクタに基づいた自律制御系の設計法}

まず，参考文献 ${ }^{(12)}$ による軌道アトラクタに基づいた自律制御系の設計法を示す．この方法は閉軌道をアトラク タとする (安定なリミットサイクルを設計する)ための設計法である . ロボットの運動方程式が

$$
\boldsymbol{x}[k+1]=\boldsymbol{f}(\boldsymbol{x}[k])+\boldsymbol{g}(\boldsymbol{x}[k]) \boldsymbol{u}[k]
$$

の状態方程式で与えられているとする .ただし,$x$ は状態変数， $\boldsymbol{u}$ は入力である .このとき，実現すべき運動を状 態空間内における $N$ 個の点からなる閉軌道

$$
\Xi=\left\{\boldsymbol{\xi}_{1} \boldsymbol{\xi}_{2} \ldots \boldsymbol{\xi}_{N}\right\}\left(\boldsymbol{\xi}_{N+1}=\boldsymbol{\xi}_{1}\right)
$$

で与え，これが軌道アトラクタとなるようコントローラ

$$
\boldsymbol{u}[k]=\boldsymbol{h}(\boldsymbol{x}[k])
$$




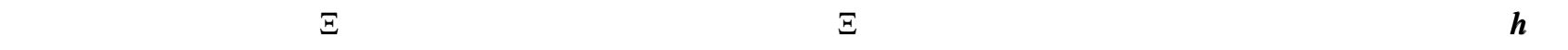

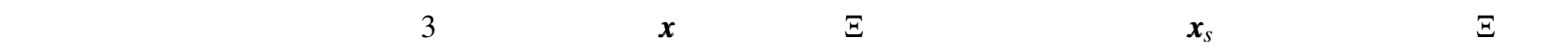

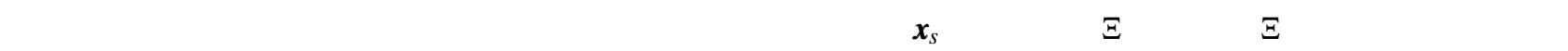
なべクトル場を定義する .これにより，状態空間内の点と光のときの入力の組 $(\boldsymbol{x}, \boldsymbol{u})$ か数多く得られる .これを

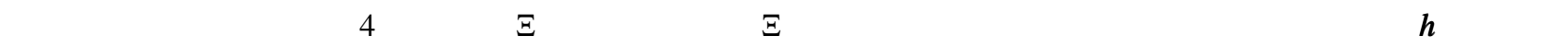
ることができる．場を作る際には式(1)を利用するため力学的に実現可能な場が得られるが , 詳細は参考文献 ${ }^{(12)} に$ 詳しい.式 (1) と (3) は图 5 に表わされる自律系を構成し, 外部からの目標値 $\boldsymbol{r}$ を必要とせずにロボットは運動 $\Xi$

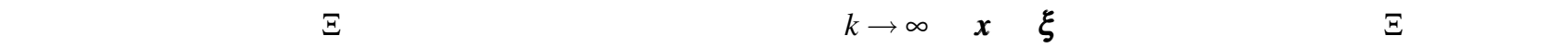
ける .

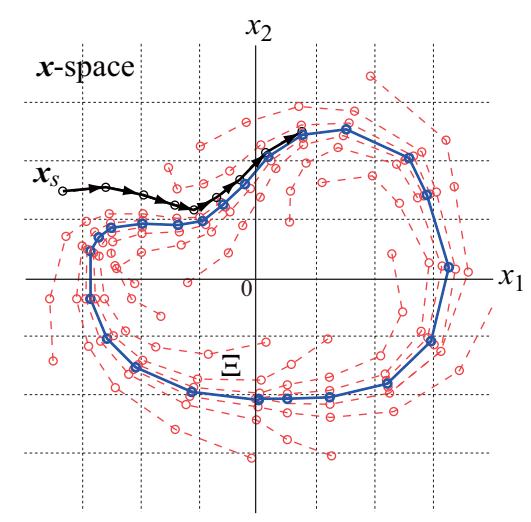

Fig. 3 Definition of the trajectries that are entrained to $\Xi$

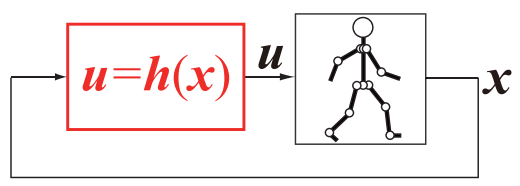

Fig. 5 Autonomous controlled system

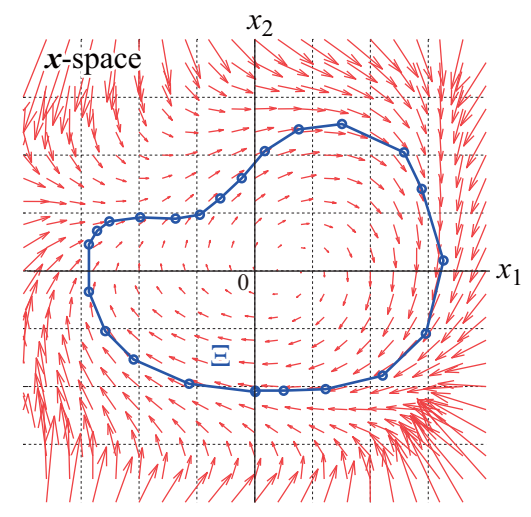

Fig. 4 Obtained vector field

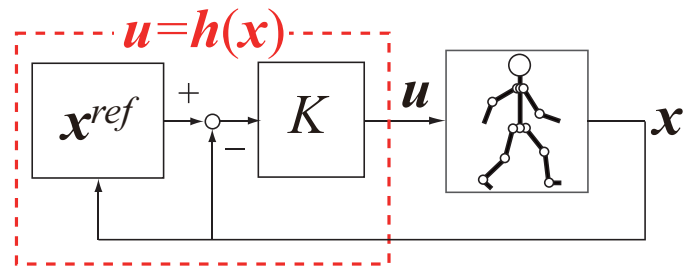

Fig. 6 Controller decomposition into $K$ and $\boldsymbol{x}^{\text {ref }}$

\section{3. 擬似目標値の設計}

2 章で得られた $\boldsymbol{h}$ に基づいて擬似目標値を設計する . 式(1)のロボットが目標值 $\boldsymbol{x}^{r e f}$ とコントローラ $K$ によって

$$
\boldsymbol{u}[k]=K\left(\boldsymbol{x}^{r e f}[k]-\boldsymbol{x}[k]\right)
$$

の制御則によって制御されている場合を考える.式(4) は状態フィードバックの形を持つがロボットの各軸 PD 制 御もこの形式で表せる .このとき, 式 (3) と (4)を見比へ , 式 (4) はロボットがるの運動を実現するための入力 $\boldsymbol{u}$ を出力しているとすると

$$
\boldsymbol{h}(\boldsymbol{x}[k])=K\left(\boldsymbol{x}^{r e f}[k]-\boldsymbol{x}[k]\right)
$$

であり，これを $x^{r e f}$ につて解くと

$$
\boldsymbol{x}^{r e f}(\boldsymbol{x}[k])=K^{\#} \boldsymbol{h}(\boldsymbol{x}[k])+\boldsymbol{x}[k]+K^{\perp} \boldsymbol{\alpha}[k]
$$

が得られる .ただし,$[\cdot]^{\#}$ は擬似逆行列,$[\cdot]^{\perp}$ は乥の補空間に属する基底からなる行列， $\alpha$ は任意のベクトルで ある.式(5) は，図 5 の $\boldsymbol{h}$ を図 6 のようにフィードバック $K$ と目標値 $\boldsymbol{x}^{r e f}$ に分解したことに相当する .すなわち， $\boldsymbol{h}$ に内在する仮想的な目標值を導出したものであり，ここでは式(6)の $\boldsymbol{x}^{r e f}$ を擬似目標値と呼ぶことにする． 
式 (4) では $K$ か溉知であるとして式 (6) を導出した．しかし，1 章で述べたように人への運動教示であれば $K$ は 未知である．乥こで， $K$ を推定して擬似目標值を導出する．いま，ロボットが未知のコントローラを用いて運動

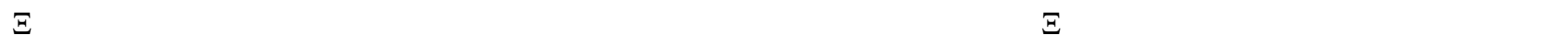

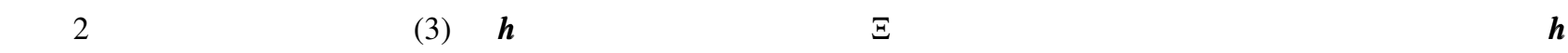
を $\Xi$ 上のる点 $\boldsymbol{\xi}$ 周りでテイラー展開し, $\boldsymbol{x} \simeq \boldsymbol{\xi}$ として 2 次以上の微小量を無視すると

$$
\boldsymbol{u}[k]=\boldsymbol{h}(\boldsymbol{\xi})-\frac{\partial \boldsymbol{h}(\boldsymbol{x}[k])}{\partial \boldsymbol{x}}(\boldsymbol{\xi}-\boldsymbol{x}[k])
$$

を得る .式 (7)の右辺第一項は, $\boldsymbol{x}$ が $\boldsymbol{\xi}$ にあるときの推進力を表しており，これはフィードフォワード項であると 見なせる .これに対し , 右辺第二項は $\boldsymbol{\xi}$ と $\boldsymbol{x}$ の差に関する項であるため $-\partial \boldsymbol{h} / \partial \boldsymbol{x}$ はフィードバックゲインである と見なすことができる．すなわち，Kが

$$
K=-\frac{\partial \boldsymbol{h}(\boldsymbol{x}[k])}{\partial \boldsymbol{x}}
$$

と推定される . 熟練者であれば $\boldsymbol{h}(\boldsymbol{\xi})$ ，すなわち，フィードフォワード項を獲得しているであろう ${ }^{(13)}$ が , これを獲 得していない初心者は $K$ と $\boldsymbol{x}^{r e f}$ から運動を実現しなければならない . 推定した $K$ を用いて式 (6) は

$$
\boldsymbol{x}^{r e f}(\boldsymbol{x}[k])=-\left(\frac{\partial \boldsymbol{h}(\boldsymbol{x}[k])}{\partial \boldsymbol{x}}\right)^{\#} \boldsymbol{h}(\boldsymbol{x}[k])+\boldsymbol{x}[k]+\left(\frac{\partial \boldsymbol{h}(\boldsymbol{x}[k])}{\partial \boldsymbol{x}}\right)^{\perp} \boldsymbol{\alpha}[k]
$$

と表される．これにより，Kが未知の場合の擬似目標值か導出された .

ここで導出された擬似目標值は以下の特徵を持つ.

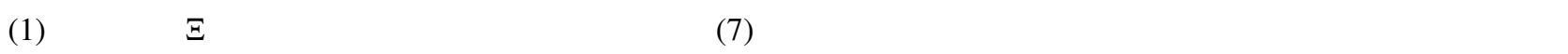

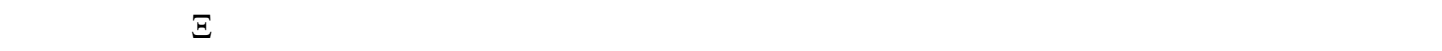

(2) 擬似目標值は安定化された自律制御系に基づいて生成される目標值であり， $K$ がロボットを安定化していな くても， $x^{r e f}$ によってロボットは安定化される .

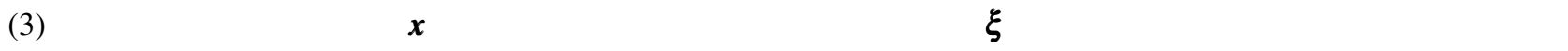
動データの中に現れる姿勢ではなく，運動実現のための強調された目指すべき姿勢となる．

(4) 自律制御系に基づいて得られる目標値であるため, $x^{r e f}$ は時間の関数ではなく $x$ の関数となる.

\section{4. 倒立振子の擬似目標値}

\section{$4 \cdot 1$ 倒立振子の周期運動}

図 7 に示す倒立振子の運動に対して擬似目標値 $x^{r e f}$ を求め，これがるを実現するための目標値となることを検 証する . 倒立振子の状態変数 $x$ は, 振子の回転角 $\theta$ と炎の角速度 $\dot{\theta}$, 台車位置 $y$ と光の速度 $\dot{y}$ を用いて,

$$
\boldsymbol{x}=\left[\begin{array}{llll}
\theta & \dot{\theta} & y & \dot{y}
\end{array}\right]^{T}
$$

により構成される . 入力 $u$ はカートに働くカである .ここでは, 運動方程式を原点周りで線形近似することで得ら

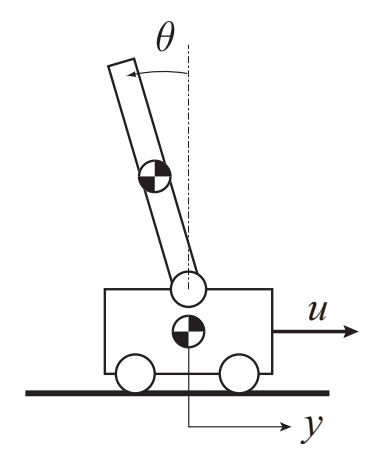

Fig. 7 Inverted pendulum system 
れる線形系を対象とする．まず，倒立振子の運動を生成するために，フィードバックゲイン $K$ を最適レギュレー タによって求め，目標值 $\boldsymbol{r}$ を図 8 にあるように台車が左右に動くような軌道として繰り返し与えた．ただし，図 8(a) は状態空間における $\boldsymbol{r}$ の軌跡であり, $\boldsymbol{\theta}, \dot{\theta}, y$ の 3 次元で示している. (b) は $\boldsymbol{r}$ を倒立振子の姿勢として表し たものである.設計した $K$ と $\boldsymbol{r}$ を用いて実現された倒立振子の運動を図 9 に示す . なお , 図 8 と同樣に , (a) は 3

(a)

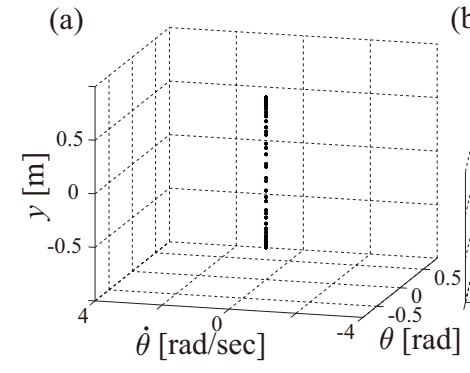

(b)

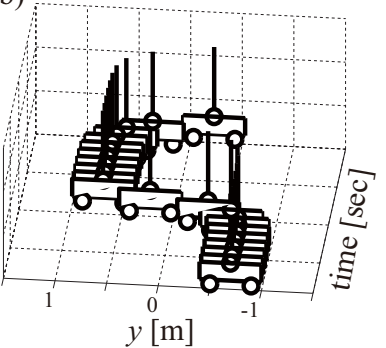

Fig. 8 Reference $\boldsymbol{r}$ for the motion (a)
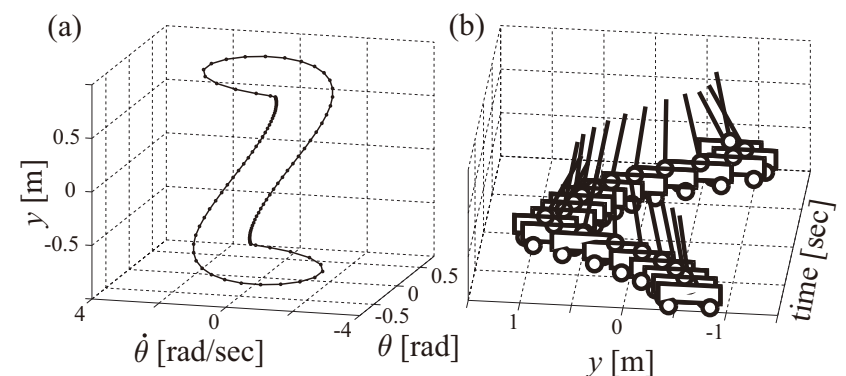

(b)

Fig. 9 Motion of the inverted pendulum with $K$ and $\boldsymbol{r}$

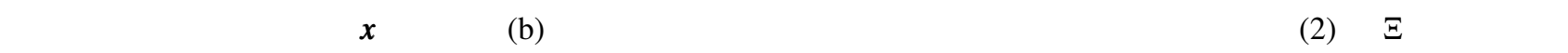

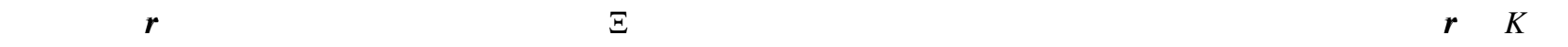
よって制御された倒立振子にすの運動を実現させるための目標値のひとつであるといえる．

\section{$4 \cdot 2$ 擬似目標値の設計}

次に，2 章の方法によって $\boldsymbol{h}$ を設計し，得られた $\boldsymbol{h}$ を用いて式(6) から擬似目標值を設計した .ただし， $\boldsymbol{\alpha}$ は以 下の評価関数 $J$ を最小化するように定めた .

$$
J[k]=w_{1}\left\|\boldsymbol{x}^{r e f}[k]-\boldsymbol{x}^{r e f}[k-1]\right\|^{2}+w_{2}\left\|W \boldsymbol{x}^{r e f}[k]\right\|^{2}, \quad W=\left[\begin{array}{cccc}
1 & 0 & 0 & 0 \\
0 & 1 & 0 & 0 \\
0 & 0 & 0 & 1
\end{array}\right]
$$

評価関数の右辺第一項は擬似目標值が時間によって大きく変化することを抑えるための評価であり，右辺第二項は $W$ によって $\boldsymbol{x}^{r e f}$ の中から $\theta, \dot{\theta}, \dot{y}$ への目標值を選択し，弚の大きさを小さくするための評価である．なお， $w_{1}$, $w_{2}$ は重み係数である. 得られた擬似目標值を図 10 に示す . 擬似目標值はほぼ 2 か所の位置で静止しており，これ

(a)

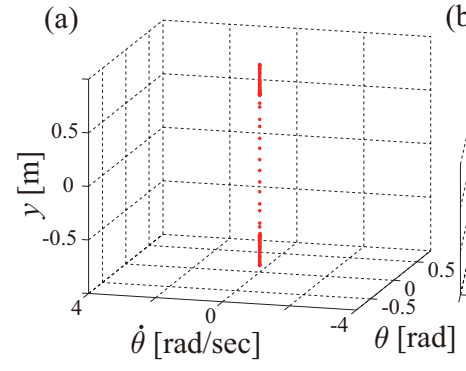

(b)

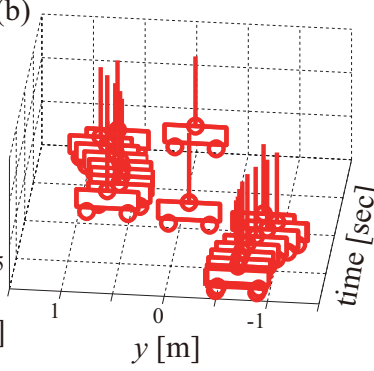

(a)

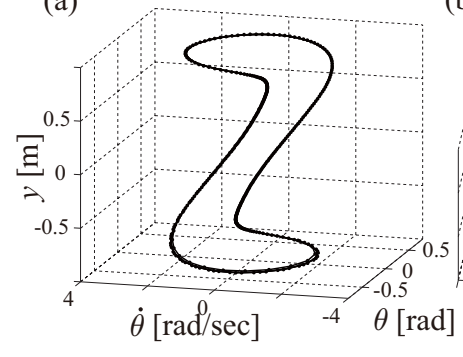

(b)

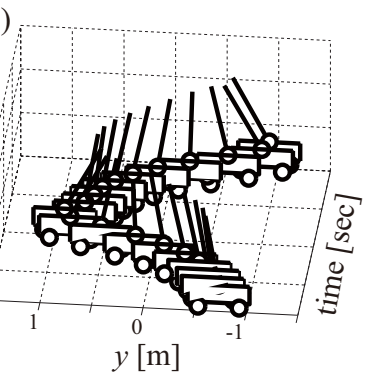

Fig. 10 Pseudo-reference of the inverted pendulum motion

Fig. 11 Motion of the inverted pendulum by autonomous controller

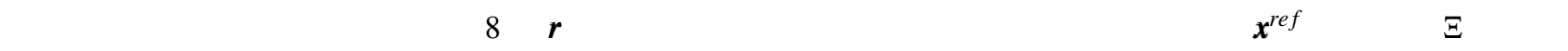
するための目標值を与えることが示される．なお，参考として $\boldsymbol{h}$ と図 5 のフィードバック系を用いて倒立振子を 自律制御した結果を図 11 に示す. 図 9 と同樣の運動が得られており，hによって図 9 の運動が自律系でモデル化 できている樣子か理解できる . 


\section{$4 \cdot 3$ 外乱による擬似目標値の変化}

$\boldsymbol{r}$ と $K$ を用いて倒立振子の運動を生成している途中に外乱を加え，このときの擬似目標值の変化を見る．4 周期 の左右への運動の中で 3 周期目に台車を零の位置へ押し戻す外乱を与え，このときの擬似目標値を求めた . この結 果を図 12 に示す. (b) の矢印で示される時刻において外力を加えている .この結果をより詳細に見るために , 外

(a)

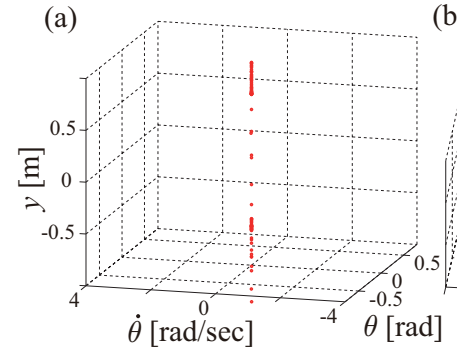

(b)

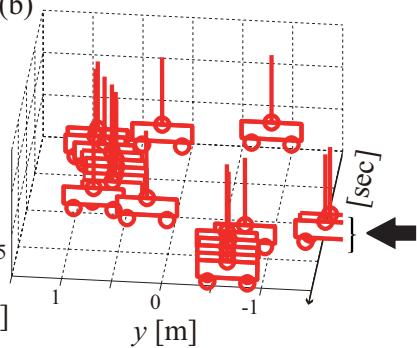

Fig. 12 Pseudo-reference with a disturbance

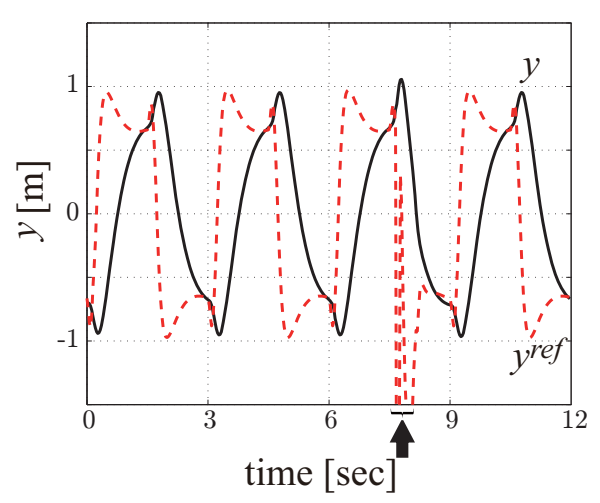

Fig. 13 Position of the cart with a disturbance

乱を加えたときの台車位置 $y$ の動きと台車位置に対する擬似目標值 $y^{r e f}$ の時系列変化を図 13 に示す . 外乱によっ て変化した倒立振子の動きを修正するための入力が発生するよう，擬似目標值の動きが変化していることが分か り，外乱などにより運動が変化した場合には，光の変化した運動に合った， るを続けるための目指すべき姿勢，す なわち，運動を安定化するための擬似目標值が得られることか理解できる .

\section{5. タップダンスロボットの擬似目標値}

\section{$5 \cdot 1$ タップダンス運動のモデル化}

本章ではタップダンスロボットの運動に対して擬似目標值を設計する . 図 14(a) に示されるタップダンスロボッ 卜を考える .このロボットは図 14(b)のように頭部を回転させるトルク $\tau$ を利用して胴体部を動かし，足の踏み替

(a)

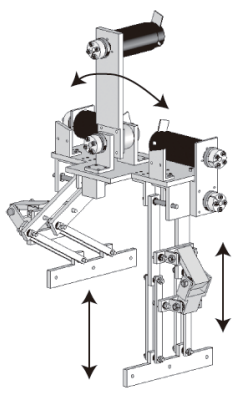

(b)

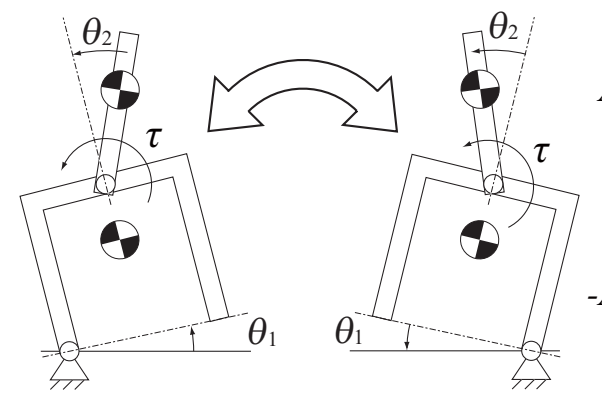

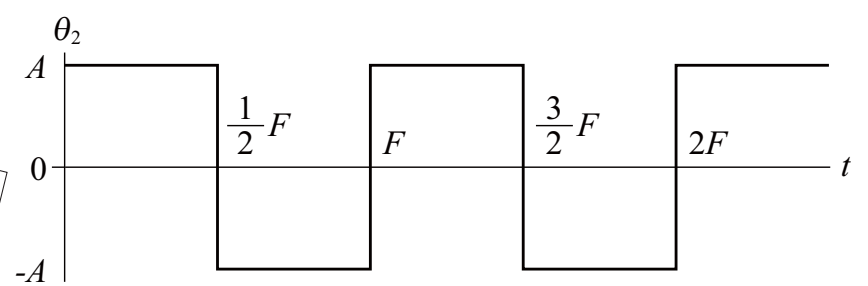

Fig. 15 Motion of $\theta_{2}$

Fig. 14 Tap dancing robot and its dynamical model

え動作 (タップダンス) を行う . 接地足の切り替わりにより運動方程式が大きく変化するため, 運動の非線形性が 強い，ただし，胴体部回転角 $\theta_{1}$, 頭部回転角 $\theta_{2}$ を図 14(b)のように定義することで, 状態変数は

$$
\boldsymbol{x}=\left[\begin{array}{llll}
\theta_{1} & \dot{\theta_{1}} & \theta_{2} & \dot{\theta}_{2}
\end{array}\right]^{T}
$$

となり，これは運動中に連続な值を取る。このロボットの機構の構成, 運動方程式については参考文献 ${ }^{(12)} に$ に詳し い. 運動の非線形性からロボットの安定化コントローラ $K$ を設計することは難しく，安定な周期運動を実現する ことは困難である.乥こで, 適当な初期姿勢から頭部回転角を图 15 のように大きさ $A$, 周期 $F$ の繰り返しステッ 
プ関数で振ることで運動を行わせたたところ，数ステップの足踏み動作を行った .この運動は極めて不安定であ り，接地時のわずかな滑りなどによって運動を続けられなくなるが，弚の中の実現された数ステップの足踏み動作 から FFT を利用して運動データを周期化し，これを運動 ことした . 得られたタップダンスロボットの運動を図 16

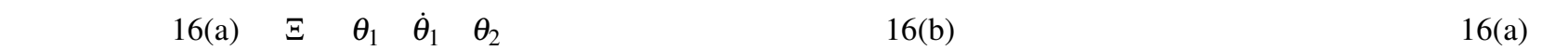

(a)

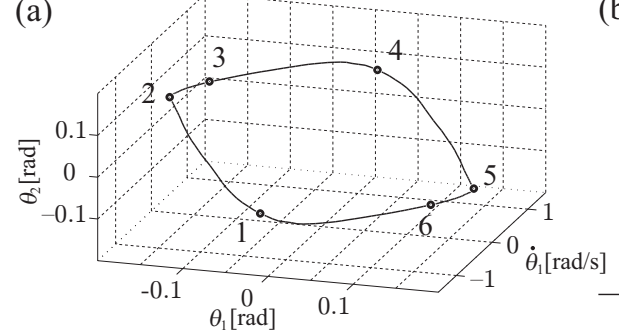

(b)

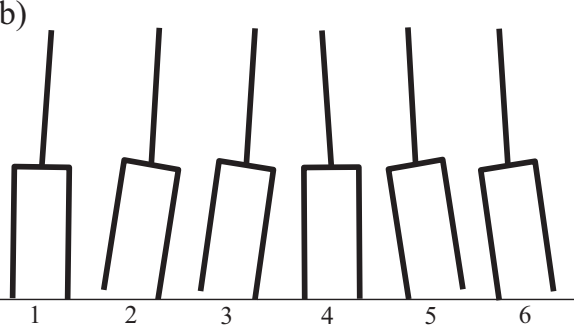

Fig. 16 Tap dancing motion

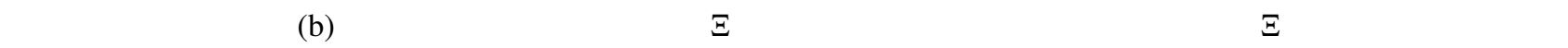
コントローラ

$$
\tau[k]=\boldsymbol{h}(\boldsymbol{x}[k])
$$

を設計して，この運動を実現する自律制御系を求めた．

\section{$5 \cdot 2$ タップダンス運動の擬似目標値}

前述のように，このロボットにタップダンス運動を生成させるための $K$ は設計されていない，光こで，まず得 られた $\boldsymbol{h}$ を用いて，ロボットにタップダンス運動を行わせた . また , $-\partial \boldsymbol{h} / \partial \boldsymbol{x}$ を $K$ の推定值とし , 式 (9) に基づ いてタップダンス運動中の擬似目標值を求めた . ただし，式 (9)における $\boldsymbol{\alpha}$ は, 以下の評価関数 $J$ を最小化する ものとした .

$$
J[k]=\left\|W_{e}\left(\boldsymbol{x}^{r e f}[k]-\boldsymbol{x}[k]\right)\right\|^{2}
$$

$W_{e}$ は重み行列を表す . これは運動中に $\boldsymbol{x}^{r e f}$ を $\boldsymbol{x}$ の近くに配置するための評価である .このときの結果を図 17 に示 す . (a) では, 実線が $x$ の軌跡, 赤い・は擬似目標值の軌跡を表している . (b) は運動中の口ボットの姿勢 (黑実線)

(a)

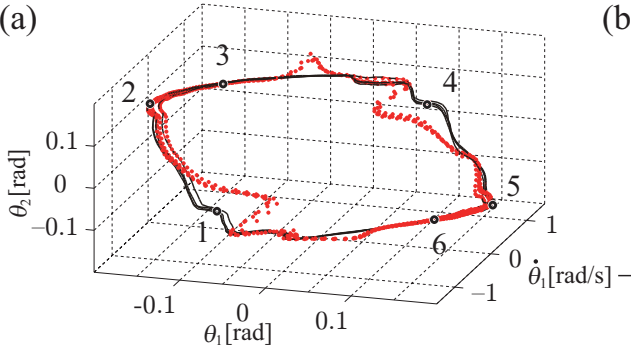

(b)

(c)

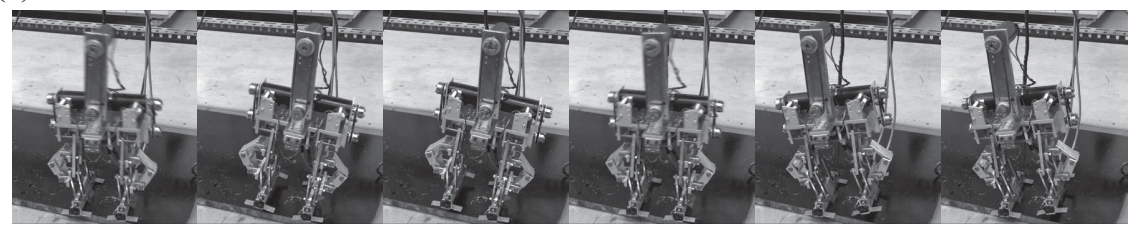

Fig. 17 Pseudo-reference of the tap dancing motion

と擬似目標値を姿勢として表したもの (赤色鎖線) を表し，(a)における番号と (b) の番号か㳔応する．また，(c) は ロボットがタップダンス運動を実現している樣子を表している．この結果から，足の踏み替え時 ((a) の 1 と 4 の 周り)に $x^{r e f}$ が $x$ から離れ，頭部を動かすためのトルクを発生させていることが分かる．より詳細に結果を見るた めに, 1 周期分の頭部角度 $\theta_{2}$ と炎の擬似目標值 $\theta_{2}^{r e f}$ の時系列変化をプロットしたものを図 18 に示す. 0 から 0.1 


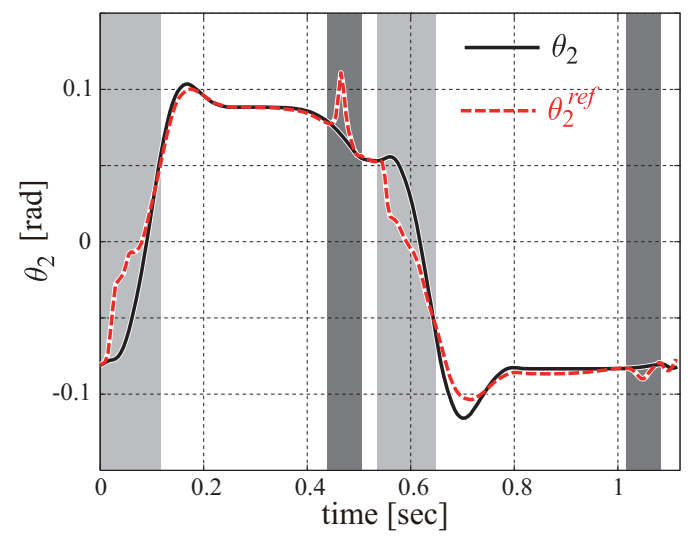

Fig. 18 Time sequence $\theta_{2}$ and its pseudo-reference $\theta_{2}^{\text {ref }}$

秒の間と 0.6 秒付近の薄い灰色領域(図 17 の 1 と 4 の周り)では, 擬似目標值は実際の姿勢に先立って目指すべき 方向へ変化している.これは制御系の遅れを考慮した目標姿勢が得られていると判断できる.また， 0.5 秒付近と 1 から 1.1 秒の間の濃い灰色領域 (図 17 の $3 \rightarrow 4$ と $6 \rightarrow 1$ の間)では，接地直前に運動の勢いをつける方向へと擬似 目標值が動いている樣子か読み取れる．以上より，推定された $K$ を用いて求めた擬似目標値も るを実現するため の適切な目標姿勢を示してくれることが分かる .さらに , タップダンスロボットの動的な運動を継続するための 制御卜ルクは常に必要なのではなく, 力を加えるタイミングが重要であり, 光のタイミングと大きさを擬似目標値 が示すと考えられる .

\section{6.お りりに}

本論文では, ロボットからロボット，あるいは，人から人への運動の伝達を目指し，目標の運動を実現するため の適切な目標姿勢を得ることを目的として擬似目標値を提案した .

1. 軌道アトラクタに基づいた自律制御系の設計手法を応用し, 現在のロボットの状態から目標の運動を実現す るための強調した目標姿勢として擬似目標值を導く方法を提案した .

2. 倒立振子を用いたシミュレーションにより，提案する擬似目標值が運動を実現するために用いた目標値一致 することを示した .これにより，擬似目標值は運動を実現するための目標姿勢としての解の 1 つを与えるこ とを示した .

3. タップダンスロボットを用いた実験により，安定化コントローラが未知の場合にも，弚の推定値を利用して 擬似目標值が得られることを示した .

本論文では，擬似目標値の提案に主眼を置き，ロボットを用いた実験によって擬似目標值が運動を実現するための 妥当な目標姿勢を与えることを示した . これを人への運動教示, 行動誘導へと応用することが今後の課題となる.

謝 辞

本研究は, 科学技術振興機構 CREST「パラサイトヒューマンネットによる五感情報通信と環境センシング・行 動誘導」，特別研究員奨励費 (23·10040) の支援を受けた．

文献

(1) 高西淳夫, 石田昌巳, 山崎芳昭, 加藤一郎, “2 足歩行ロボット WL-10RD による動歩行の実現”, 日本ロボット学会誌, Vol.3, No.4 (1985), pp.67-78.

(2) 梶田秀司, 小林涁, “位置エネルギー保存形軌道を規範とする動的 2 足歩行の制御”, 計測自動制御学会論文集, Vol.23, No.3 (1987), pp.281-287.

（3）真島勝行, 宮崎敏昌, 大石潔, “絶対座標系の動作記述とキネマティクスに基づいた 2 足ロボットの動歩行制御の実現”, 電気 学会論文誌 C, Vol.117, No.11 (1997), pp.1566-1572. 
(4) Nishiwaki K., Sugihara T., Kagami S., Inaba M. and Inoue H., "Online mixture and connection of basic motions for humanoid walking control by footprint specification", Proc. of the 2001 IEEE International Conference on Robotics and Automation (ICRA2001) (2001), pp.4110-4115.

(5) Harada K., Kajita S., Kaneko K. and Hirukawa H., "An analytical method on real-time gait planning for a humanoid robot", Proc. of 2004 IEEE/RAS International Conference on Humanoid Robots (Humanoids2004) (2004), pp.640-655.

(6) 西脇光一, 加賀美聡, “ヒューマノイドのための短周期オンライン歩行軌道生成更新法”, 計測自動制御学会論文誌, Vol.25, No.6 (2007), pp.834-841.

(7) 杉原知道, 中村仁彦, “境界条件緩和法による 2 脚ロボットのオンライン運動計画”, 日本ロボット学会誌, Vol.25, No.7 (2007), pp.1082-1091.

(8) Fu C. and Chen K., "Gait Synthesis and Sensory Control of Stair Climbing for a Humanoid Robot", IEEE Transactions on Industrial Electronics, Vol.55, No.5 (2008), pp.2111-2120.

(9) Perrin N., Stasse O.,Baudouin L.,Lamiraux F. and Yoshida E., "Fast Humanoid Robot Collision-Free Footstep Planning Using Swept Volume Approximations", IEEE Transactions on Robotics, Vol.28, No.2 (2012), pp.427-439.

(10) 金島義治, 菅原雄介, 安藤俊平, 佐藤基広, Lim H-O, 高西淳夫, “2 足ヒューマノイドロボットの準リアルタイムパターン生 成に関する研究”, 第 19 回日本ロボット学会学術講演会予稿集 (2001), pp.987-988.

(11) 池田貴幸, 篠原隆之, 美多勉, “可変拘束制御を用いた三次元脚式ロボットの走行制御”, 日本ロボット学会誌, Vol.21, No.1 (2003), pp.94-102.

(12) 岡田昌史, 村上健治, “軌道アトラクタを用いたロボットの同調運動制御によるコミュニケーション原理の表現”, 日本ロボッ 卜学会誌, Vol.25, No.4 (2007), pp.545-553.

(13) 川人光男, “小脳の学習と内部モデル (眼球運動を題材に)”, 日本神経回路学会誌, Vol.9, No.2 (2002), pp.132-139. 